\title{
Policies and Practices for Entrepreneurial Education in Malaysia: A Review
}

\author{
Siti Farhah Fazira Binti Shamsudin ${ }^{*}$
}

\author{
Abdullah Al Mamun² \\ Noorshella Binti Che Nawi² \\ Noorul Azwin Binti Md Nasir² \\ Mohd Nazri Bin Zakaria ${ }^{2}$
}

${ }^{1}$ Graduate Research Assistant, Faculty of Entrepreneurship and Business, Universiti Malaysia Kelantan

2Senior Lecturer, Faculty of Entrepreneurship and Business, Universiti Malaysia Kelantan

${ }^{*}$ Corresponding Author, Email: farhah.a14d014f@siswa.umk.edu.my

Doi:10.5901/mjss.2016.v7n2p36

\section{Abstract}

Entrepreneurship is viewed as one of the key economic development strategies to advance a country's economic growth and to sustain its competitiveness in facing the increasing trends of globalization. The Malaysian government has made tremendous efforts in promoting entrepreneurship education across the country. This paper therefore aims to review the programs and policies, together with empirical studies on entrepreneurial education, and its effects on students' entrepreneurial intentions. Finally, the review of the policies and practices in Malaysia shows that the government is mostly focused on the following aspects: improving the current policy on entrepreneurship education, providing various entrepreneurship programs to increase the number of young entrepreneurs, and highlighting the need to empower entrepreneurship education among graduates of HEls.

Keywords: Entrepreneurship Education, Entrepreneurial University, Malaysian University

\section{Introduction}

For decades, the world has evolved to a place where the economy is of great concern to a country. The economy plays a vital role in measuring the success of every country around the globe. Thus, each country is determined to find numerous ways to improve their economy and one of the widely known options is through entrepreneurship. Indeed, many governments around the world believe that the key to economic development is entrepreneurship (Hebert \& Link, 2011) including Malaysia (Mohamed et al., 2012).

Many scholars and economists are also in favor of the fact that entrepreneurship is an essential factor in the advancement of a society (Abu-Saifan, 2012). Kuratko (2005) emphasized that entrepreneurship has established its position as the most powerful economic force over the last decades. In addition, entrepreneurship is viewed as the engine that drives the economy and as a result, there is a rising attention in the progression of education programs that promote entrepreneurship (Gorman, Hanlon, \& King, 1997). This is proven by "the number of colleges and universities that offer courses related to entrepreneurship that has grown from a handful in the 1970s to over 1600 in 2005" (Katz, 2003).

Several studies have suggested that entrepreneurship can be taught or somehow motivated through entrepreneurship education (Gorman et al., 1997; Kuratko, 2005). According to Jones and English (2004), entrepreneurial education is "the process of providing individuals with the ability to recognize commercial opportunities and the insight, self-esteem, knowledge, and skills to act on them". Moreover, entrepreneurship education can also be considered as the organized formal transfer of entrepreneurial competencies, that refer to the concepts, skills, and mental awareness that individuals use in the process of starting and developing their growth-oriented ventures (Alberti et al., 2004; Ogundele, Akingbade \& Akinlabi, 2012).

Many countries are recognizing the importance of entrepreneurship and are embracing it as a way to enhance employment and economic development (Ahmad, 2013; Ali et al., 2010). In addition, there are several existing agreements concerning the significance of encouraging entrepreneurship to "stimulate economic development, create wealth, and employment generation in Malaysia and other developing economies" (Ahmad \& Xavier, 2012). More 
importantly, entrepreneurship has been viewed as the "panacea to the unemployment problem" (Ahmad, 2013). Putting it differently, entrepreneurship is perceived as a solution to reduce the unemployment rate.

In recent years, the unemployment problem among graduates has been a main issue in Malaysia (Ahmad, 2013). The Economic Planning Unit and the Department of Statistics (2013) reported a fluctuation of the unemployment rate in Malaysia between 2008 and 2013. The Ministry of International Trade and Industry (2014) further reported in its weekly bulletin that around 0.4 million people were still unemployed as at February 2014. According to Lebusa (2011), the real situation today is that more and more graduates are joining the unemployment queue. Young and fresh graduates, in particular, experience difficulties in securing their first job (Ismail, 2011). According to Ariff, Ghadas, Muslim, and Hamid (2014), "as the number of graduates exceeds the market demand, the unemployment rate of fresh graduates also increase". This is due to the lack of job opportunities available (Ismail, 2011; Ooi, Selvarajah, \& Meyer, 2011). Hence, entrepreneurship particularly entrepreneurship education is one of the best solutions to reduce the dependency of graduates on being employed (Ariff et al., 2014). Therefore, in order to deepen the understanding of entrepreneurship education in Malaysia, this paper intended to review existing policies and programs for entrepreneurial education in Malaysia.

\section{Entrepreneurial Education Policies}

As mentioned by many scholars, entrepreneurship is viewed as an engine that drives the economy (Ali et al., 2010; Gorman, Hanlon, \& King, 1997; Mohamed et al., 2012). Moreover, according to Temtime, Chinyoka, and Shunda (2004), there is a universal agreement among public policy makers, academics, and researchers that entrepreneurship is a crucial key to economic advancement for many countries. Thus, governments around the world have become interested in providing supportive environments that would promote enterprises and build new ventures (Kirby, 2004). This can be seen by looking at the way the governments have been spending to create entrepreneurs (Dana, 2001) through entrepreneurship education. Entrepreneurship education has also been a priority on the European agenda during the last ten years (Anne Støren, 2014). Moreover, many countries have launched action plans to promote entrepreneurship education. Both academics and policy makers shared the growing interest in entrepreneurship education and its outcomes (Hytti, 2010).

Among the policies that are carried out by the Malaysian government are the New Economic Policy - NEP (19711990), the National Development Policy - NDP (1991-2000), and the New Economic Model - NEM (2010) (Othman, Othman, \& Ismail, 2012a). The implementation of NEP was due to racial clashes that happened on 13 May 1969. It was an initiative undertaken by the government to correct the economic imbalances among races (Gomez, 2003). The outcome of the NEP was commendable as it was reported that the poverty rate in Peninsular Malaysia had decreased from 49.3\% in 1970 to 16.5\% in 1990. Following this in 1991, the NDP was introduced (Economic Planning Unit, 2004). The NDP emphasized on growth with equity that allowed all Malaysians to take part in the economic activities, thus ensuring political stability and national unity (Economic Planning Unit). Subsequently, the New Economic Model - NEM was launched on 30 March 2010 by the Prime Minister, YAB Dato Seri Mohd. Najib Tun Abd. Razak. This policy was expected to be a good plan in making Malaysia a fully developed country as envisioned in Vision 2020. In addition, under this new policy, the government has also highlighted the need to build entrepreneurship in creating a competitive domestic economy (National Economic Advisory Council, 2010). Thus, by looking at these three early policies, it could be said that the development of entrepreneurship in Malaysia has long been emphasized by the government. However, the policies do not yet show the government's target on entrepreneurship education specifically for graduates of Higher Education Institutions (HEls).

\subsection{Higher Education Entrepreneurship Development Policy (2010)}

The introduction of a policy shows the emphasis of the government on the importance of integrating entrepreneurial values and cultures among Higher Education Institutions' (HEIs) graduates. Higher Education Entrepreneurship Development Policy is the current policy concerning entrepreneurship education that was launched on $13^{\text {th }}$ April 2010 by the Ministry of Education (MOE). The aim of this policy is to boost the development of more holistic and well-organized entrepreneurship programs. Specifically, the implementation of the policy aims to produce graduates from HEls with thinking and entrepreneurial attributes as well as to increase the number of entrepreneurs among graduates who are engaged in businesses as a catalyst for the achievement of economic transformation in the country from a middle to a high income economy while producing academics with values, skills, thoughts, and entrepreneurship qualities at the same time. 
In order to achieve these aims, six thrusts were introduced under the policy. The first thrust is to establish an Entrepreneurship Institute in every Higher Education Institute (HEI). The second thrust is to provide holistically and wellplanned entrepreneurial programs and development. The third thrust is to empower entrepreneurial development and programs. The fourth thrust is to create an effective measuring mechanism. The next thrust is to provide a conducive environment and ecosystem for entrepreneurship development. The final thrust is to enhance the competency of entrepreneurship trainers.

Following the launch of the policy, the MOE as well as the HEls have taken a number of initiatives to implement entrepreneurial education and development to increase the number of entrepreneurs among the Malaysian young generation. HEls have also shown a high interest in the agendas of the policy. As a result, students' involvement in the entrepreneurial programs and activities as well as their readiness in choosing entrepreneurship as a career choice has increased. However, there are still issues and challenges in ensuring the success of entrepreneurial education and development agendas. Among the issues are in terms of the effectiveness of the Entrepreneurship Institute in every HEl, the plan and management of entrepreneurial education, the competency of the trainers, the existence of a conducive ecosystem, strategic cooperation between academy and industry/entrepreneur/alumni, the government's policy and internal organizational rules, and entrepreneurship as a career choice. Thus, a more practical and pragmatic approach should be introduced to make sure the executed teaching pattern is able to produce more skillful entrepreneurial graduates.

\subsection{Strategic Plan on Entrepreneurship Development in Higher Education (2013-2015)}

In empowering the implementation of entrepreneurial education in the Malaysian Higher Education as well as in ensuring the aim of the Higher Education Entrepreneurship Development Policy is achieved, the Strategic Plan on Entrepreneurship Development in Higher Education (2013-2015) was launched on 21 April 2013. This Strategic Plan aims to improve the six thrusts that have been implemented by proposing fifteen main strategies after taking into account the challenges and current achievements of the HEls. The six thrusts that have been improved are presented below.

Table 1: The six thrusts for 2010 and 2013

\begin{tabular}{|c|c|c|}
\hline & -2010 & Year- 2013 \\
\hline a. & Establish an Entrepreneurship Institute in every HEl. & a. $\quad$ Empowering Entrepreneurship Institute in every HEI. \\
\hline & $\begin{array}{l}\text { Provide holistically and well-planned entrepreneurial } \\
\text { education and programs. }\end{array}$ & $\begin{array}{l}\text { b. Provide holistically and well-planned entrepreneurial education } \\
\text { and programs. }\end{array}$ \\
\hline c. & Empowering the entrepreneurial development programs. & Empowering the entrepreneurial development programs. \\
\hline & Create an effective measuring mechanism. & $\begin{array}{l}\text { d. Enhance the competency of HEls' entrepreneurship trainers and } \\
\text { facilitators. }\end{array}$ \\
\hline e. & $\begin{array}{l}\text { Provide a conducive environment and ecosystem for } \\
\text { entrepreneurship development. }\end{array}$ & $\begin{array}{l}\text { e. Provide a conducive environment and ecosystem for } \\
\text { entrepreneurship development. }\end{array}$ \\
\hline & Enhance the competency of entrepreneurship trainers. & $\begin{array}{l}\text { f. Increase the effect of the implementation of HEls' entrepreneurial } \\
\text { education and development. }\end{array}$ \\
\hline
\end{tabular}

Source: Kementerian Pengajian Tinggi Malaysia (2013)

Table 2: The improved six thrusts and the fifteen proposed strategies.

\begin{tabular}{ll}
\hline Thrusts & Strategies \\
\hline Empowering the Entrepreneurship Institute in every HEI. & $\begin{array}{l}\text { Boost the function of the Entrepreneurship Institute in every HEI. } \\
\text { Improve the Entrepreneurship Institute planning and informing system. }\end{array}$ \\
\hline $\begin{array}{l}\text { Provide holistically and well-planned entrepreneurial } \\
\text { education and programs. }\end{array}$ & $\begin{array}{l}\text { Integrate entrepreneurial values and attributes in the teaching method } \\
\text { across curriculum and faculty. } \\
\text { Increase the practical element in entrepreneurship education. } \\
\text { Increase the involvement of industrial workforce in the teaching and } \\
\text { learning process. } \\
\text { Increase active student involvement in entrepreneurship programs. }\end{array}$ \\
\hline Empowering the entrepreneurial development programs. Strengthen the support system for student's business. \\
Offer high impact interventional programs to the students who have \\
higher tendency towards an entrepreneurship career. \\
Encourage the development of entrepreneurship programs that are
\end{tabular}




\begin{tabular}{ll}
\hline & $\begin{array}{l}\text { based on businesses, which are beneficial to the students, (SMEs) as } \\
\text { well as the society. }\end{array}$ \\
\hline $\begin{array}{l}\text { Enhance the competency of HEIs' entrepreneurship } \\
\text { trainers and facilitators. }\end{array}$ & $\begin{array}{l}\text { Increase the number of trainers and facilitators that are competent and } \\
\text { skillful. } \\
\text { Bridge the gap of entrepreneurial theory and practical knowledge } \\
\text { among HEls' trainers. }\end{array}$ \\
& $\begin{array}{l}\text { Improve the skills and competencies of the entrepreneurship trainers } \\
\text { and facilitators. }\end{array}$ \\
\hline $\begin{array}{l}\text { Provide a conducive environment and ecosystem for } \\
\text { entrepreneurship development. }\end{array}$ & $\begin{array}{l}\text { Improve commitment of the higher management of HEIs. } \\
\text { Improve the commitment and involvement of every person in the HEls. }\end{array}$ \\
\hline $\begin{array}{l}\text { Increase the effect of the implementation of HEIs' } \\
\text { entrepreneurial education and development. }\end{array}$ & $\begin{array}{l}\text { Establish a suitable instrument to measure the effect and impact of } \\
\text { HEls' entrepreneurship education and development programs. }\end{array}$ \\
\hline
\end{tabular}

Source: Kementerian Pengajian Tinggi Malaysia (2013)

\section{Entrepreneurial Education Programs}

Along with the implemented policies, the Malaysian government has also introduced various entrepreneurship programs. The Ministry of Education (MOE) has mainly been playing its part in promoting entrepreneurship education across the country. According to Othman, Othman, and Ismail (2012b), the MOE has been conducting entrepreneurship acculturation in schools for a long time. This activity begins in primary schools; such as when entrepreneurial elements are introduced in Mathematics. Meanwhile in secondary schools, the stress on the importance of entrepreneurship education can be seen when the students are compulsory to study Integrated Living Skills that was initiated in the year 1991, which includes components of commerce and entrepreneurship (Mohamed et al., 2012). The constant effort is also shown when students can choose Commerce and Entrepreneurship Education as elective subjects in vocational and technology streams in the upper secondary school (Mohamed et al., 2012; Othman et al., 2012b).

There was also a Young Entrepreneurs Programme (PUM) organized in secondary schools as informal learning that aimed to foster the entrepreneurial spirit among the students. The program was introduced in 1989 and was run by the National Entrepreneurship Institute (INSKEN). The core purpose of the program was to expose the students and to let them experience the ways of managing the establishment and dissolution of companies based on the co-operative model. The students were involved in a hands-on training program for nine months, and at the end of the program, they presented the year-end profit and loss account of their company. Recently, INSKEN has also introduced a set of entrepreneurship programs. One of the programs include Program Usahawan Bimbing Usahawan (Coaching by Industry Players) where a minimum of $70 \%$ of the training modules are developed and delivered by industry players and professionals in a series of seminar, training, and coaching. In addition, the Program Pembangunan Permulaan Perniagaan (Start-Up Business Accelerator Program) is another program that targets the participation of students. This program aims to increase the number of university graduates venturing into business. Among the offered sub-programs are SUPERB Business Training and Coaching, High Potential Student Entrepreneurs, and Students Enterprise Starting Global (INSKEN, 2015).

Furthermore, the Kedah State Development Corporation (PKNK), an agency that is supervised by the Ministry of Finance, has promoted many entrepreneurial development programs. These programs are aimed at producing professional and middle class natives, and PKNK works in grooming and mentoring business entrepreneurs to become successful entrepreneurs so that they have the confidence to face business challenges through the Entrepreneurs Fund Program, Entrepreneurship Culture Program, the Business Development Program, and Organizing Program Trade Mission. In addition, the Program Penyediaan Infra Usahawan can help Bumiputera entrepreneurs to own business premises at a strategic and viable location. Other programs that have been organized by the PKNK include Business Coaching \& Mentoring Program, Franchise Development Program, and Advanced Training and Enhancement Program (PKNK, 2015).

Lastly, apart from these measures provided by the government, there is another program that is worth being highlighted. The 1Malaysia Entrepreneurs program, or 1MET, was launched by the Malaysian government to support entrepreneurs from all parts of the society to start and develop their own business successfully by empowering public and private sector resources. The main objective of the organization of $1 \mathrm{MET}$ is to help Malaysia to become a high-income nation that consists of individuals who are genuinely entrepreneurial. In addition, the government aims to produce 5000 youth entrepreneurs annually through these programs. Thus, a series of entrepreneurship boot camps were designed to notify nascent and new entrepreneurs in the basics of entrepreneurship such as venture building through the 1MET 
program. Strategic sub-initiatives have also been introduced in order to achieve the objectives that have been set upon the organization of the program.

\section{Conclusion}

Overall, it can be concluded that the Malaysian government has taken tremendous efforts in promoting entrepreneurship across the country. There are a number of supporting mechanisms provided and various policies implemented by the government for entrepreneurs. In terms of education, the Ministry of Education has long emphasized the need to focus on entrepreneurship education through its own educational policies. However, the programs and policies of entrepreneurship education in Malaysia still require some improvement. Therefore, it is important for the Ministry of Education and Higher Education Institutions to join hands in making sure that the current policies and programs as well as the curriculum and content on entrepreneurship are improved to produce holistic graduates with entrepreneurial and balanced skills as stated in the latest Malaysian Education Blueprint (Higher Education) (2015-2025) as well as to develop the nation's human capital through education as envisioned in Vision 2020. In order to achieve this status, Malaysia, which is currently a middle income country, needs to focus on promoting entrepreneurship education since it has spread from developed countries, such as the USA and Europe (Ahmad, 2013).

This paper has reviewed the entrepreneurial programs and policies in Malaysia, while mentioning some empirical studies on entrepreneurial education and its effects on students' entrepreneurial intentions. It is shown that the government is mostly focused on the following aspects: improving the current policy on entrepreneurship education, providing various entrepreneurship programs to increase the number of young entrepreneurs, and highlighting the need to empower entrepreneurship education among graduates of HEls. Future researches should discuss the efforts and measures taken by Malaysian universities in helping Malaysian government to promote entrepreneurship education across the country so that entrepreneurship education in Malaysia would be able to attain a completely new level of success in educating future entrepreneurs.

\section{References}

Abu-Saifan, S. (2012). Social entrepreneurship: definition and boundaries. Technology Innovation Management Review, 2(2), 22-27.

Ahmad, S. Z. (2013). The need for inclusion of entrepreneurship education in Malaysia lower and higher learning institutions. Education + Training, 55(2), 191-203.

Ahmad, S. Z., \& Xavier, S. R. (2012). Entrepreneurial environments and growth: evidence from Malaysia GEM data. Journal of Chinese Entrepreneurship, 4(1), 50-69.

Alberti, F., Sciascia, S., \& Poli, A. (2004). Entrepreneurship education: notes on an ongoing debate. In Proceedings of the 14th Annual IntEnt Conference, University of Napoli Federico II, Italy, 4-7 July.

Ali, I., Tajddini, K., Rehman, K., Ali, J. F., \& Ahmed, I. (2010). University Student 's inclination of Governance and its Effects on Entrepreneurial Intentions : an Empirical Analysis. International Journal of Trade, Economics and Finance, 1(1), 36-39.

Anne Storen, L. (2014). Entrepreneurship in higher education. Education + Training, 56(8/9), 795-813.

Ariff, Z., Ghadas, A., Muslim, H., \& Hamid, Z. (2014). 'Legal Eagle' Entrepreneurship Education for Law Students : Special Reference to International Islamic University Malaysia, Pertanika Journal of Social Sciences \& Humanities, 22, 83-98.

Dana, L. P. (2001). The education and training of entrepreneurs in Asia. Education + Training, 43(8/9), 405-416.

Economic Planning Unit - EPU. (2005). Achieving Growth with Distribution. Ninth Malaysia Plan 2006-2010. Available from: http://www.epu.gov.my/epu-theme/RMK6/Chapter\%201\%20\%20Policy\%200bjectives \%20and\%20Framework.pdf. (Accessed: 28 July 2015)

Gomez, E. T. (2003). Affirmative action and enterprise development in Malaysia: the new economic policy, business partnerships and inter-ethnic relations. Kajian Malaysia, 21(1-2), 59-104.

Gorman, G., Hanlon, D., \& King, W. (1997). Some research perspectives on entrepreneurship education, enterprise education and education for small business management: a ten-year literature review. International Small Business Journal, 15(3), 56-77.

Hebert, R. F., \& Link, A. N. (2011). A History of Entrepreneurship. International Journal of Business and Social Science, 2(9), 241-242.

Hytti, U., Stenholm, P., Heinonen, J., \& Seikkula-Leino, J. (2010). Perceived learning outcomes in entrepreneurship education: The impact of student motivation and team behaviour. Education + Training, 52(8/9), 587-606.

Institut Keusahawanan Negara (INSKEN). Start-up Business Accelerator Program. Available from: http://www.insken.gov.my/index.php/ program/program-pembangunan-perniagaan-permulaan-start-up-business-accelarator-program.( Accessed on 21 July 2015)

Ismail, N. (2011). Graduates' characteristics and unemployment: A study among Malaysian graduates. International Journal of Business and Social Science, 2(16), 94-102.

Jones , C., \& English , Jack . (2004). A contemporary approach to entrepreneurship education. Education + Training, 46(8/9), 416-423.

Katz, J. a. (2003). The chronology and intellectual trajectory of American entrepreneurship education 1876-1999. Journal of Business Venturing, 18(2), 283-300. 
Kementerian Pengajian Tinggi Malaysia. (2013). Pelan Strategik Keusahawanan Institusi Pengajian Tinggi 2013-2015. 5-7.

Kirby, D. a. (2004). Entrepreneurship education: can business schools meet the challenge? Education + Training, 46(8/9), 510-519.

Kuratko, D. F. (2005). The emergence of entrepreneurship education: Development, trends, and challenges. Entrepreneurship Theory and Practice, 29(5), 577-598.

Lebusa, M. J. (2011). Does Entrepreneurial Education Enhance Under-graduate Students' Entrepreneurial Self-efficacy ? A Case at one University of Technology in South Africa, China-USA Business Review. 10(1), 53-64.

Mansor, M., \& Othman, N. (2011). CoBLAS: Inculcating Entrepreneurial Culture among Higher Education Institutions' Students. International Journal of Social Science and Humanity, 1(1), 86-91.

Ministry of International Trade and Industry. (2014). MITI Weekly Bulletin. Vol. 290. 14 May 2014.

Mohamed, Z., Rezai, G., Shamsudin, M. N., \& Mahmud, M. M. (2012). Enhancing young graduates' intention towards entrepreneurship development in Malaysia. Education + Training, 54(7), 605-618.

National Economic Advisory Council. (2010). New Economic Model for Malaysia. Available from:http://www.mampu.gov.my/ documents/ 10228/25989/27-07-04-2010-economicmodel_malaysia.pdf/8834e445-db30-4822-9e37-8548499e361c. (Accessed on 29 July 2015)

Ogundele, O. J. K., Akingbade, W. A., \& Akinlabi, H. B. (2012). Entrepreneurship training and education as strategic tools for poverty alleviation in Nigeria. American International Journal of Contemporary Research, 2(1), 148-156.

Ooi, Y. K., Selvarajah, C., \& Meyer, D. (2011). Inclination towards entrepreneurship among university students: An empirical study of Malaysian university students. International Journal of Business and Social Science, 2, 206-220.

Othman, N., Othman, N. H., \& Ismail, R. (2012a). Impact of globalization on entrepreneurship education and entrepreneurial skills in higher education institutions. In 2012 2nd International Conference on Economics, Trade and Development. Singapore: IACSIT Press, 36, 84-89.

Othman, N., Othman, N. H., \& Ismail, R. (2012b). Impact of Globalization on Trends in Entrepreneurship Education in Higher Education Institutions, International Journal of Trade, Economics and Finance, 3(4): 267-271

Perbadanan Kemajuan Negeri Kedah (PKNK). Available from http://www.pknk.gov.my/index.php?option=com_content\&view=article\& id=613:pembangunan-usahawan\&catid=58:usahawan\&ltemid=113 (Accessed on 24 July 2015) 